\title{
Effects of polycythaemia and haemodilution on circulation in neonates
}

\author{
Verena H A Mandelbaum, Carlos D Guajardo, Mathias Nelle, Otwin Linderkamp
}

\begin{abstract}
Haemodilution in nine neonates resulted in significant mean (SEM) decrease of packed cell volume $(0.67(0.01)$ to 0.55 $(0.01))$ and increases in cardiac output (250 (16) to 308 (25) $\mathrm{ml} / \mathrm{min} / \mathrm{kg}$ ) and blood flow velocities of the internal carotid artery and the coeliac artery $(+20 \%)$. However, red cell flows in the aorta, carotid and coeliac arteries did not change during haemodilution, thereby indicating that haemodilution did not improve oxygen transport.

(Arch Dis Child 1994; 71: F53-F54)
\end{abstract}

Neonatal polycythaemia increases the risk of pulmonary hypertension, renal failure, necrotising enterocolitis, cerebral ischaemia, intracranial haemorrhage, and developmental retardation. ${ }^{1}$ The clinical manifestations of polycythaemia result from the rise in blood viscosity. ${ }^{2}$ Previous studies have shown that cardiac output and cerebral blood flow velocity in polycythaemic neonates increased more than $30 \%$ during isovolaemic haemodilution (partial exchange transfusion)..$^{13}$

Blood flow in gastrointestinal arteries of polycythaemic infants has not been studied. However, experiments in puppies have shown that polycythaemia decreases gastrointestinal blood flow by more than $40 \%{ }^{4}$ The present study was designed to evaluate the effects of polycythaemia and haemodilution on cardiac output and blood flow velocities of cerebral and coeliac arteries in newborn infants.

\section{Subjects and methods}

Nine neonates with a packed cell volume above 0.60 and signs of polycythaemia (for example, cyanosis, increased respiration rate, or jitteriness) ${ }^{1}$ were studied at between 4 and 120 hours of birth (polycythaemic group). Their gestational age ranged from 33 to 41 weeks and their birth weight ranged from 2800 to $4410 \mathrm{~g}$. Nine healthy neonates with gestational age of 34 to 40 weeks and birth weight of 2900 to $3800 \mathrm{~g}$ with a packed cell volume below 0.60 were studied at between 6 and 120 hours of birth (control group). The study protocol was approved by the ethical committee of the University Hospital Centre of Heidelberg. Informed consent was obtained from the parents in each case. In each group, five infants were born by caesarean section, and four were delivered vaginally. All infants had birth weights appropriate for their gestational age (10th to 90 th centile according to the Munich charts). The umbilical cords were clamped within 20 seconds of birth. In the polycythaemic infants, isovolaemic haemodilution was performed with serum (Biseko, Biotest) via an umbilical vein catheter. The haemodilution procedure lasted about two hours and was continued until the packed cell volume was about $0 \cdot 55$.

Cardiovascular measurements in the polycythaemic infants were done before and one to two hours after haemodilution. During the examinations, infants were either sleeping or quiet and in supine position. Blood flow velocities and cardiac output were measured using an Interspec XL pulsed Doppler ultrasound system (Interspec Inc). Details of the cardiac output method have been reported elsewhere. ${ }^{5}$ Systolic blood flow velocities were measured using a $5.0 \mathrm{MHz}$ pulsed Doppler transducer. The arteries were identified by duplex scan mode. The right and left internal carotid artery were localised via the anterior fontanelle. As there were no significant differences between the two internal carotid arteries, the mean velocities of both arteries were calculated for each infant. The coeliac artery was localised by ultrasound from a longitudinal abdominal section and blood flow velocity was determined close to the origin of the artery from the abdominal aorta.

Packed cell volume was determined by the microhaematocrit method. Mean arterial blood pressure was measured in the right and left upper arm using an oscillometric technique (Dinamap 847, Critikon). Systemic flow resistance was calculated as mean pressure to cardiac output ratio.

\section{Results}

The packed cell volume decreased from mean (SEM) $0.67(0.01$ ) (range 0.63 to 0.70 ) before isovolaemic haemodilution to $0.55(0.01)$ (range 0.52 to 0.58 ) after the procedure (table). Cardiac output and blood flow velocities of the internal carotid artery and the coeliac artery were significantly decreased in the polycythaemic infants when compared with the control group. During haemodilution, the blood flow parameters in the polycythaemic group increased to the values of the control group. The increase in cardiac output was mainly due to a rise in stroke volume, whereas the heart rate increased only slightly. Red blood cell flow was calculated as the product of cardiac output or blood flow velocity times packed cell volume. These calculated red cell flow values and systolic blood pressure were similar in polycythaemic and control infants and did not change with haemodilution. Systemic blood flow resistance 
Effects of polycythaemia and isovolemic haemodilution on circulation in neonates

\begin{tabular}{|c|c|c|c|c|}
\hline & \multirow[b]{2}{*}{$\begin{array}{l}\text { Control } \\
\text { infants }\end{array}$} & \multicolumn{3}{|c|}{ Polycythaemic infants } \\
\hline & & $\begin{array}{l}\text { Before } \\
\text { haemodilution }\end{array}$ & $\begin{array}{l}\text { After } \\
\text { haemodilution }\end{array}$ & Difference \\
\hline Packed cell volume (PCV) & $0.54(0.01)^{\star}$ & $0.67(0.01)$ & $0.55(0.01)$ & $0.12(0.01)^{\star}$ \\
\hline $\begin{array}{l}\text { Systolic blood pressure } \\
\text { (P, mm Hg) } \\
\text { Stroke volume (ml/kg) } \\
\text { Heart rate (beats/min) } \\
\text { Cardiac output }\end{array}$ & $\begin{array}{l}54(1) \\
2 \cdot 4(0 \cdot 1)^{\star} \\
124(3)\end{array}$ & $\begin{array}{l}58(5) \\
2 \cdot 0(0 \cdot 2) \\
122(4)\end{array}$ & $\begin{array}{l}57(2) \\
2 \cdot 4(0 \cdot 2) \\
127(3)\end{array}$ & $\begin{array}{l}-1(3) \\
0 \cdot 4(0 \cdot 2)^{\star} \\
5(3)\end{array}$ \\
\hline $\begin{array}{l}(\mathrm{Q}, \mathrm{ml} / \mathrm{min} / \mathrm{kg}) \\
\text { Red cell flow }(\mathrm{Q} \times \mathrm{PCV})\end{array}$ & $\begin{array}{l}296(14)^{\star} \\
159(11)\end{array}$ & $\begin{array}{l}250(16) \\
167(10)\end{array}$ & $\begin{array}{l}308(25) \\
171(12)\end{array}$ & $\begin{array}{c}58(10)^{\star} \\
4(10)\end{array}$ \\
\hline $\begin{array}{l}\text { Systemic flow resistance } \\
(R=P / Q) \\
\end{array}$ & $18(1)^{\star}$ & $26(9)$ & $19(2)$ & $-7(3)^{\star}$ \\
\hline $\begin{array}{l}\text { Blood flow velocities }(\mathrm{cm} / \mathrm{sec}) \\
\text { Internal carotid artery }(\mathrm{ICA}) \\
\text { ICA } \times \text { PCV } \\
\text { Coeliac artery (CA) } \\
\text { CA } \times \text { PCV }\end{array}$ & $\begin{array}{l}42(3)^{\star} \\
24(2) \\
68(3)^{\star} \\
36(2)\end{array}$ & $\begin{array}{l}34(2) \\
23(2) \\
58(3) \\
39(2)\end{array}$ & $\begin{array}{l}41(4) \\
22(2) \\
69(3) \\
38(2)\end{array}$ & $\begin{aligned} &(3)^{\star} \\
&-1(2) \\
& 11(3)^{\star} \\
&-1(2)\end{aligned}$ \\
\hline
\end{tabular}

Data are mean (SEM) $95 \%$ confidence intervals around the mean values and the mean differences can be calculated as $2 \cdot 306 \times$ SEM

${ }^{\star} \mathrm{p}<0.05$ when compared to the polycythaemic infants before haemodilution. An unpaired $t$ test was used to compare control and polycythaemic infants and a paired $t$ test was used to test for changes in the measured parameters in the polycythaemic infants during haemodilution.

(blood pressure/cardiac output) decreased with haemodilution according to the rise in cardiac output.

\section{Discussion}

From the present data we conclude that cardiac output and blood flow velocities in cerebral and gastrointestinal arteries of polycythaemic neonates increase significantly as a result of isovolaemic haemodilution. However, systemic red blood cell transport was not affected by polycythaemia and haemodilution. Assuming that the blood flow velocities in the cerebral and coeliac arteries reflect the actual blood flows, red cell flows to the brain and the gastrointestinal tract were also not altered by haemodilution (table). Swetnam et al observed that cardiac output increased by $32 \%$ and systemic oxygen transport increased by $13 \%$ immediately after exchange transfusion. ${ }^{3}$ This may be explained by a higher packed cell volume (mean 0.72 ) before haemodilution.

Systemic blood flow resistance (computed as systolic blood pressure to cardiac output ratio) decreased with haemodilution according to the rise in cardiac output (table). Flow resistance is often used as an indicator of vessel diameter, but in circular vessels it is the product of blood viscosity and vascular hindrance (that is, vessel geometry) ${ }^{5}$ In the present study, blood viscosity was not measured. However, blood viscosity calculated from previously published nomograms ${ }^{2}$ decreased by the same percentage $(-20 \%)$ as systemic flow resistance. This suggests that the decrease in systemic flow resistance during haemodilution was due to a decrease in blood viscosity, whereas vascular hindrance probably remained unchanged.

In human adults, systemic red cell flow and red cell transport to most organs tend to decrease at packed cell volume values above $0 \cdot 55,{ }^{6}$ whereas our results suggest that in neonates red cell flow does not change up to a packed cell volume of $0 \cdot 70$. Different circulatory responses of adults and neonates to polycythaemia may be due to altered vessels in adults $^{5}$ or to favourable rheological properties of neonatal blood. ${ }^{2}$ Blood viscosity in neonates decreases less with rising packed cell volume than in adults when viscosity measurements are done in a narrow tube with a diameter of $50 \mu \mathrm{m}$. In these narrow tubes, transport of neonatal blood does not significantly change when the packed cell volume is increased from 0.50 to 0.70 , whereas in adults red cell transport decreases at packed cell volumes above $0 \cdot 60 .^{2}$

We conclude that polycythaemia and haemodilution in neonates do not affect systemic, cerebral, and gastrointestinal oxygen transport in neonates as long as the packed cell volume does not exceed $0 \cdot 70$.

This study was supported by Research Grant Li 291/4 from the Deutsche Forschungsgemeinschaft. The authors thank Vivian M Vargas, MSBA, for her help in preparing the manuscript.

1 Oh W. Neonatal polycythemia and hyperviscosity. Pediatr Clin North Am 1986; 33: 523-32.

2 Linderkamp O, Stadler A, Zilow EP. Blood viscosity and optimal hematocrit in preterm and full-term neonates in optimal hematocrit in preterm and full-term neona

3 Swetnam SM, Yabek SM, Alverson DC. Hemodynamic Swetnam SM, Yabek SM, Alverson DC. Hemodynamic 110: 443-7.

4 Kotagal UR, Keenan WJ, Reuter JH, Steichen JJ, Kleinman LI. Regional blood flow in polycythemia and hypervolemia. Pediatr Res 1977; 11: 394

5 Mandelbaum VHA, Alverson DC, Kirchgessner A, Linderkamp $O$. Postnatal changes in cardiac output and haemorheology in normal neonates born at full term. Arch Dis Child 1991; 66: 391-4.

6 Schmid-Schönbein H. Macrorheology and microrheology of blood in cerebrovascular insufficiency. Eur Neur 1983; 22 (suppl 1): 2-22. 